\title{
The Effect of Summer Engineering Camps on Students' Interest in STEM (Evaluation)
}

\section{Ms. Jessica Marie Faber,}

Jessica is a student at Wartburg College studying Engineering Science with a minor in Creative Writing and Mathematics. She is active with soccer at Wartburg and works for the innovation Studio in the Engineering department.

\section{Luke G Grzech, Wartburg College}

Luke is a Student in the Engineering Science Department at Wartburg College. He is getting his major in Engineering Science and Minors in Mathematics and Leadership. Research interests include recruitment into STEM and diversity in STEM.

\section{Murad Musa Mahmoud, Wartburg College}

Murad is an Assistant Professor at the Engineering Science Department at Wartburg College. He has a $\mathrm{Ph} . \mathrm{D}$. in Engineering Education from Utah State University. Research interests include recruitment into STEM, diversity in STEM as well pedagogy and instruction.

\section{Prof. Kurt Henry Becker, Utah State University - Engineering Education}

Kurt Becker is the current director for the Center for Engineering Education Research (CEER) which examines innovative and effective engineering education practices as well as classroom technologies that advance learning and teaching in engineering. He is also working on National Science Foundation (NSF) funded projects exploring engineering design thinking. His areas of research include engineering design thinking, adult learning cognition, engineering education professional development and technical training. He has extensive international experience working on technical training and engineering educaton projects funded by the Asian Development Bank, World Bank, and U.S. Department of Labor, USAID. Countries where he has worked include Armenia, Bangladesh, Bulgaria, China, Macedonia, Poland, Romania, and Thailand. In addition, he teaches undergraduate and graduate courses for the Department of Engineering Education at Utah State University. 


\section{The Effect of Summer Engineering Camps on Students' Interest in STEM (Evaluation)}

\section{Introduction}

Science, Technology, Engineering, and Mathematics, also known as STEM, are fields that have become increasingly important in the economic growth of the United States. STEM plays an essential role in the development of new ideas and technology, and drives discovery. With a constant new stream of jobs, and growth in many STEM related occupations, there is a rising demand for qualified people to fill those roles [1]. However, in comparison to past generations, student interest and literacy in STEM subjects have been declining [2]. The large gap between females and males entering STEM fields is also an area of concern. While females earn slightly more than $50 \%$ of degrees in psychology, biological sciences, and social sciences and about $40 \%$ of mathematics degrees, in the fields of engineering, computer sciences and physical sciences, women earn approximately $20 \%$ of degrees [3]. Currently, there is a concerning combination of a growing job market and a lack of students, especially females, entering STEM fields. Due to this, it has become increasingly important to increase student interest in STEM.

A common tool for stimulating STEM interest is through informal STEM educational programs, such as after school activities or summer camps. Unlike the typical classroom setting, these programs can help students learn about and experience STEM in various ways. Attending these programs could potentially help students develop skills and an understanding of STEM subjects needed for higher education and to better their future [4]. These types of programs have the potential to generate interest in students who are relatively new to STEM and also continues to encourage students who already express interest [5][6][7][8]. STEM enrichment programs could prove to be a vital resource in STEM student recruitment.

The focus of this study is to determine how STEM summer camps influence student interest levels. Interest levels preceding and following the camps will be examined, as well as what types of factors help contribute to these interest levels. Interest levels of male and female students will also be examined. Determining exactly how STEM summer camps impact different students and their interest levels in STEM can be useful to encourage students to pursue STEM and fill the needed STEM roles in the workforce.

\section{Program Description}

Students and teachers from multiple school districts in Utah were invited to attend a week-long summer engineering camp at the campus of Utah State University. The camp was designed to increase their interest in STEM. The camps took place in the summers of 2017, 2018 and 2019. The camps were part of a 7-year grant funded by the Department of Education as part of the GEAR UP program. The grant's overall goal is to help more than 3,000 middle and high school students to improve their academic achievement, creating a pipeline of academically prepared students enrolling and excelling in college. During the summer camps, STEM teachers and students participated in a variety of engineering activities. They developed research hypotheses, proposed methods to test those hypotheses, and thought like engineers. Participating teachers applied the research and engineering camp activities to develop classroom lessons for their science classroom to meet the Next Generation Science Standards (NGSS) framework which had 
engineering as a fundamental component. The number of participating students in the 2017 camp was 33 and the number of teachers was 10. For the 2018 and 2019 camps, the number of participating students was 44 in each and the number of teachers was also 10 each.

Participant demographics for student participants are shown in Table 1 below.

Table 1. Demographics of student participants

\begin{tabular}{cc}
\hline Category & Number (Percentage) \\
\hline Age in years N (\%) & \\
14 & $43(35.5 \%)$ \\
15 & $50(41.3 \%)$ \\
16 & $28(23.1 \%)$ \\
Sex N (\%) & \\
Male & $66(54.5 \%)$ \\
Female & $55(45.5 \%)$ \\
Ethnicity N (\%) & \\
White & $85(70.2 \%)$ \\
Asian & $4(3.3 \%)$ \\
Hispanic & $24(19.8 \%)$ \\
Other & $3(2.5 \%)$ \\
American Indian or Native Alaskan & $5(4.1 \%)$ \\
\hline
\end{tabular}

As to be expected, most of the students were the same age at 14, 15 and 16 years old (eighth graders going into ninth grade for the 2017 camp and ninth graders going into tenth grade for the 2018 camp, and tenth graders going into eleventh for the 2019 camp). Most of the student participants were also from the White ethnicity (70.2\%). Hispanic students made up $19.8 \%$ of the sample. Asians and Native Americans also made up 3.3\% and $2.5 \%$ of the population, respectively, and other ethnicities represented $4.1 \%$ of the sample. Those numbers were comparable to the Census data for Utah where the research was conducted. The distribution of sexes was almost even with $54.5 \%$ male and $45.5 \%$ female.

The program was designed to promote hands-on learning and minimized passive classroom learning. The main theme of both engineering camps was water and environmental engineering. The 2018 camp included advanced water engineering including drones used in agriculture and air quality engineering. Before the camp activities started, students completed a pre-camp survey to determine their perceptions of and interest in STEM, as well as the factors influencing that interest. The same survey was given to students at the end of the engineering camp to determine the impact the camp experience had on improving the students' perception and increasing their interest in STEM, as well as examine which factors influenced that interest. This research focused on the differences between males and females in terms of the factors influencing their interest in STEM fields. 
Below is a description of activities the students and teachers were involved in during the 2017, 2018 and 2019 camps. After the description of each activity, sample quotes were included. Those quotes were taken from the journals students wrote at the end of each day.

\section{Engineering Camp 2017:}

The first day of the engineering camp included activities to pique the students' interest in using STEM activities to better manage water resources. The day began with an activity showing students the water cycle and illustrate the amount of available fresh water for human use in the hope of increasing their appreciation for the scarcity of usable water. The results of this activity showed up many times in the daily journals students wrote as they learned more about the importance of water conservation. The water cycle activity was followed by a fish tagging activity. This included how the fish tagging process was done, the importance of it, and how scientists and engineers use the process to determine the health of streams and movement of fish in the stream. With the aid of a graduate student in Fisheries Biology, students had the opportunity to engage in the practice of tagging fish.

During the second day of the engineering camp students visited three sites along a river in a local water shed. The first stop was upstream in the mountains where the river is fed from melting snow. The second stop was downstream of camping, fishing, kayaking and other recreational uses of the water at a point just before the river enters the city. The final stop was after the river had passed through the city, farms and ranches in the area. At each stop, students took various physical and chemical measurements of the water including temperature, flow velocity and volume, dissolved oxygen, turbidity, and nutrient concentrations including phosphates and nitrates. The students also collected and characterized macro invertebrates living in the river. The point of this activity was to show the students what happens physically, chemically, and biologically to the water as it flows downstream, passes through a city, and changes in response to the influence of human civilization. The day's activities also included a hike to a beaver dam.

The third day of the engineering camp focused on storm water impacts and water treatment. This included a simulated storm water activity comparing run-off volume and intensity as rainfall was simulated on an area covered in vegetation and another area covered with asphalt/concrete to show the potential impact of urban development (increases in impervious surface areas). The students then visited a parking lot storm water system at a local chain box store and observed the plants used to filter pollutants running off of the parking lot such as oil/gas. Those pollutants get washed away by the rain, but before the water entered the storm water system, it passed through this thick vegetation area and is cleaned by the specialized plants. Students also had the opportunity to see what happens as a non-reactive fluorescent tracer (simulated pollution) is dumped into the local river and observed how fast and how far pollution can spread. Finally, teams of students competed at building a water filter from sand and gravel. Faculty and student researchers judged the quality of the filters based on the clarity of the filtered water as well as the speed at which the filter worked.

The fourth day of the engineering camp focused on wastewater treatment plants. Students looked at bacteria under the microscope and saw some of the bacteria that are at work at 
biological treatment plants such as the ones they would visit later that day. After learning about bacteria related to treatment plants, students visited a local treatment lagoon and wetland system that filters the water of the surrounding county. Students then sampled and analyzed water quality parameter at a mechanical treatment plant. The students learned the differences between the two treatment methods as well as their advantages and disadvantages.

During the final day (Day 5) of the engineering camp, students presented what they had learned in a poster session followed by a presentation session. Finally, students completed a post survey to gauge their learning and what had changed about their perceptions of STEM.

Table 2 shows a summary of the activities students and teachers engaged in during the weeklong engineering camp in 2017.

Table 2. Outline of the weeklong engineering camp 2017

\begin{tabular}{|c|c|c|c|c|}
\hline Day & Activity 1 & Activity 2 & Activity 3 & Activity 4 \\
\hline Monday & Water Cycle & Fish tagging & & \\
\hline Tuesday & $\begin{array}{c}\text { Measuring water } \\
\text { properties at } \\
\text { multiple locations } \\
\text { along a local river, } \\
\text { starting upstream } \\
\text { and then going all } \\
\text { the way } \\
\text { downstream. }\end{array}$ & & & \\
\hline Wednesday & $\begin{array}{l}\text { Water Run off } \\
\text { experiment }\end{array}$ & $\begin{array}{l}\text { Storm water } \\
\text { impacts/multiple } \\
\text { location }\end{array}$ & River Dye activity & $\begin{array}{l}\text { Building and testing } \\
\text { a water filter }\end{array}$ \\
\hline Thursday & $\begin{array}{l}\text { Looking at bacteria } \\
\text { under a microscope }\end{array}$ & $\begin{array}{l}\text { Site visit to local } \\
\text { lagoons treatment } \\
\text { facility, sampling } \\
\text { and analysis of } \\
\text { water quality } \\
\text { parameters }\end{array}$ & $\begin{array}{l}\text { Site visit to local } \\
\text { mechanical } \\
\text { wastewater } \\
\text { treatment facility, } \\
\text { sampling and } \\
\text { analysis of water } \\
\text { quality parameters }\end{array}$ & \\
\hline Friday & Poster Session & Presentation Session & & \\
\hline
\end{tabular}

\section{Engineering Camp 2018 and 2019}

The camps in 2018 and 2019 were structured differently from the 2017 camp. Instead of all the students and teachers being together all week, the students were split into four groups, and aside from the first and last day, each group was doing something different. The groups rotated through the four activities during the week, and all students experienced all activities. This allowed for more interaction between the faculty engineers and undergraduate students that facilitated the camp.

The first day of the camp, students filled out a pre-survey similar to the 2017 camp, and then they attended a short presentation by each of the facilitators of the activities to pique the students' interest and get them prepared for what they would be doing the rest of the week. Next, the groups of students participated in assembling simple submarines/submersible ROVs 
(Remotely Operated Vehicles) to use during the week to check water parameters such as temperature and turbidity (water clarity) as well as take underwater videos.

The second and third days of the camp involved students participating in all four activities described below. The activities were:

Sea Perch Submarines: Students took the ROVs (Remotely Operated Vehicles) they had assembled on the first day to the local river dam reservoir and used remote controllers to maneuver the submarines in the water, collected water samples, gathered a variety of data and took underwater videos using Go Pro cameras.

GIS Stream Data: Students went to the water lab affiliated with the university to gather stream data on the river. The students checked water depth and water flow at multiple depths. They also measured some water properties.

Air Quality/Drones: Students learned about air quality and methods of measuring air quality. They assembled a simple sensor that tells them the quality of the air based on the color of the LED light that gets activated by the pollutant particles in the air. They also collected vertical air quality data as a drone carrying more advanced sensors was flown over an open area at the university to measure air quality.

Flying Aggies: Students learned about the use of drones in agriculture and how the images drones captured could provide valuable information about what steps farmers could take to improve their fields.

The fourth day: During the evening before the fourth day, groups of students picked which of the four activities they experienced earlier in the week they would like to spend more time on and go in it in more detail. Each group developed a research question about the topic, collected data, and analyzed the data.

During the final day of the engineering camp, students presented what they had learned in a research poster session followed by a presentation session. At the end of the engineering camp students completed a post survey to gauge what had changed about their perceptions of STEM.

Table 3 shows a summary of the activities students and teachers engaged in during the weeklong engineering camp in 2018 and 2019. The table followed one of the groups, the other groups would have had slightly different schedules.

Table 3. Outline of the weeklong engineering camp 2018

\begin{tabular}{|l|l|l|}
\hline Day & Activity 1 & Activity 2 \\
\hline Monday & $\begin{array}{l}\text { Presentations summarizing the } \\
\text { activities for the week }\end{array}$ & Building submersible ROV's \\
\hline Tuesday & Sea Perch Submarines & GIS Stream Data \\
\hline Wednesday & Air Quality/Drones & Flying Aggies \\
\hline Thursday & Activity choice & Working on Poster and Presentation \\
\hline Friday & Poster and Presentation Sessions & \\
\hline
\end{tabular}




\section{Data Collection}

\section{Students' Pre and Post Surveys}

The first day students arrived at each engineering camp they completed a pre-survey which contained demographic questions and the STEM-CIS Career Interest Survey, based on the work of Kier, Blanchard, Osborne, \& Albert [9]. This survey measured the attitudes and interest of students towards STEM fields and has four sections, each pertaining to one part of STEM. Each section included 11 questions for a total of 44 questions. The STEM CIS included questions such as, "I am interested in careers that involve engineering". The survey was a 5-point Likert scale from 'Strongly Agree' to 'Strongly Disagree'.

At the end of each engineering camp, students completed the post-survey. The pre and post surveys contained the same set of questions concerning interest in STEM. The post-survey also included students' ratings of the various camp activities.

Qualitative data was collected using open ended questions in both the pre and post surveys. The students also filled daily journals about their experiences of the day. The questions included: "What made you choose to come to this camp?", "Name in order the three biggest influences on your choice of career in the future", "I would like you to write about your experience with STEM (Science, Technology, Engineering, and Mathematics) fields", "Are you interested in a STEM (Science, Technology, Engineering, and Mathematics) career? Why or why not?"

\section{Data Analysis}

The quantitative data collected from the STEM CIS surveys was analyzed using a statistical package (SPSS). The analysis involved finding the differences in interest for the participating students between the pre and post survey.

A significance test (Two Tailed Student's T-Test) was conducted for four different groups, the first was the full sample of 121 students, the second was for the female students $\mathrm{N}=55$, the third was for the male students $\mathrm{N}=66$, and the fourth was for the group of students that started the camp with low interest in STEM. Low interest was defined as 3 or lower on a 5-point scale. This is similar to the work done by Hernandez et al. [10] and was replicated by Mahmoud et al. [7].

The nature of the camps examined in this research is that they attract students who volunteer to participate, which could explain their high initial interest in STEM [11]. Additionally, the GEAR UP program targets students from low-income families. Those two factors indicate that the sample is not random or representative of the total population of Utah or the United States of America and thus will not be generalizable.

Qualitative data was collected in the pre and post surveys using open ended questions. The data was then coded using the coding software MaxQDA. Coding was completed by two undergraduate students under the supervision of a faculty advisor who trained the two students in the process of qualitative analysis. Coding followed recommendations from the literature. 
Specifically, the Coding Manual for Qualitative Researchers by Saldana [12] as well as the Qualitative Inquiry and Research Design book by Creswell [13].

Both the undergraduate students and faculty advisor read through the data multiple times before coming to an agreement on the major themes contained in the data and creating a coding table. The data was coded based on the three themes: "Interested in STEM", "Undecided", "Not Interested in STEM".

During the first cycle of coding, the coders and faculty advisor found and discussed the subthemes which were used in the second cycle of coding. During both the first and second cycles of coding, the coders met to arbitrate the results until agreement was made on the codes. The target was an interrater reliability Cronbach's Alpha of 0.8 [14] The target interrater reliability was reached for both cycles of coding.

The results from coding the qualitative data was then interpreted in conjunction with those from the quantitative portion. This was completed according to recommendations from the literature about mixed methods research, such as Creswell's book, Designing and Conducting Mixed Methods Research [15].

\section{Results}

Qualitative Data

This section presented the results from coding the qualitative data. Three main categories regarding interest levels were established, and under each category, six subcategories were coded to determine what impacts the interest levels of students in STEM.

Table 4: Qualitative Data Results

\begin{tabular}{lcccccc}
\hline & \multicolumn{2}{c}{ Pre } & \multicolumn{2}{c}{ Post } \\
& Female & Male & Total & Female & Male & Total \\
\hline Interested in STEM & 36 & 55 & 91 & 41 & 57 & 98 \\
Undecided & 11 & 7 & 18 & 7 & 7 & 14 \\
Not Interested & 8 & 4 & 12 & 7 & 2 & 9
\end{tabular}

Table 4 shows the change in interest levels before and after the camp and the frequency of various factors that influenced student interest. The levels of interest were coded under one of three main categories: "Interested in STEM", "Undecided", and "Not Interested in STEM". The largest difference in the three categories before and after the camps was an increase of 7 for the category "Interested in STEM". "Interested in STEM" also had the highest frequency with 91 students interested before the camp and 98 interested after the camp. One male student explained his interest in STEM by writing, "I am interested in having a career in technology and engineering because I want to help make things that will benefit others and make people's lives easier if possible." A female student wrote, "I absolutely love the science field and I'm good 
when it comes to studying and enjoy getting out in the field rather than staying cooped up all day."

The category "Undecided" had the largest decrease of 4 in their frequency following the camp. There were 18 students in this category preceding the camp and 14 students after the camp. When asked if he was interested in a STEM career, a male student responded, "Yes and no. Yes, cause it would be a great career path to follow, but also no because I want to pursue other things like music or acting in musicals." A female student wrote about her interest in STEM saying, "Possibly. I'm good at science and math but I'm not sure yet if its the type of career I want to pursue." Both students were open to the idea of pursuing STEM, but were not interested enough to commit to STEM.

There was a decrease of 3 in the category of "Not Interested in STEM". Before the camp, the number of students that were considered "Not interested in STEM" was 12, and the number after was 9. A female student expressed she was not interested in STEM when she wrote, "No. I really want to be an artist, and that is my goal." Another male student explained how while he might not be currently interested in STEM, he was open to the possibility. He wrote in response to being asked if he was interested in a STEM career, "Not at the moment, but it probably will come over me"

In Figure 1, the frequency of responses regarding the interest levels of students before and after the camp is shown. The bar graph showed the number of responses into each of the three categories before and after the camp.

\section{Student Interest Levels Before and After Camp}

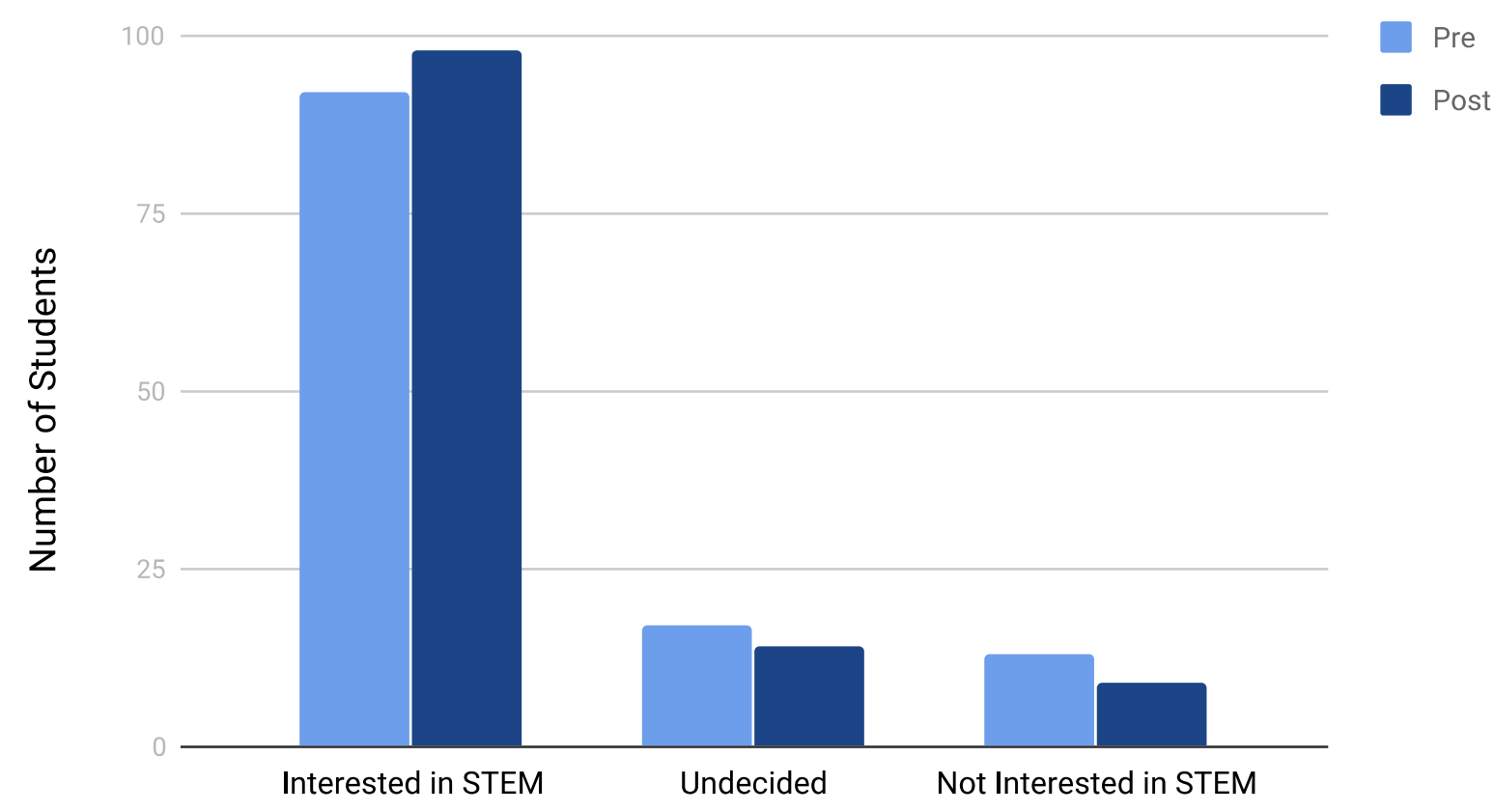

Figure 1: Student Interest Levels Before and After Camp 
Tables 5-7 show a breakdown of the sub-categories coded under each of the three main categories.

Table 5: Subcategory Data Results Interested in STEM

\begin{tabular}{|c|c|c|c|c|c|c|}
\hline & \multicolumn{3}{|c|}{ Pre } & \multicolumn{3}{|c|}{ Post } \\
\hline & Female & Male & Total & Female & Male & Total \\
\hline \multicolumn{7}{|c|}{ Interested in STEM } \\
\hline Career/Future Plans & 27 & 39 & 66 & 27 & 40 & 67 \\
\hline Fun/Enjoyable & 16 & 11 & 27 & 10 & 8 & 18 \\
\hline STEM Subjects & 16 & 23 & 39 & 9 & 7 & 16 \\
\hline $\begin{array}{l}\text { Engaging/Hands-on } \\
\text { Activities }\end{array}$ & 6 & 9 & 15 & 8 & 5 & 13 \\
\hline Ability & 4 & 1 & 5 & 1 & 2 & 3 \\
\hline Camps & 0 & 2 & 2 & 5 & 4 & 9 \\
\hline
\end{tabular}

Table 6: Subcategory Data Results Undecided

\begin{tabular}{|c|c|c|c|c|c|c|}
\hline & \multicolumn{3}{|c|}{ Pre } & \multicolumn{3}{|c|}{ Post } \\
\hline & Female & Male & Total & Female & Male & Total \\
\hline \multicolumn{7}{|c|}{ Undecided } \\
\hline Career/Future Plans & 9 & 2 & 11 & 5 & 3 & 8 \\
\hline STEM Subjects & 3 & 1 & 4 & 0 & 1 & 1 \\
\hline Camps & 0 & 0 & 0 & 1 & 1 & 2 \\
\hline $\begin{array}{l}\text { Engaging/Hands-on } \\
\text { Activities }\end{array}$ & 1 & 0 & 1 & 0 & 0 & 0 \\
\hline Ability & 0 & 0 & 0 & 0 & 1 & 1 \\
\hline Fun/Enjoyable & 0 & 0 & 0 & 0 & 0 & 0 \\
\hline
\end{tabular}


Table 7: Subcategory Data Results Not Interested in STEM

\begin{tabular}{|c|c|c|c|c|c|c|}
\hline & \multicolumn{3}{|c|}{ Pre } & \multicolumn{3}{|c|}{ Post } \\
\hline & Female & Male & Total & Female & Male & Total \\
\hline \multicolumn{7}{|c|}{ Not Interested in STEM } \\
\hline Career/Future Plans & 8 & 3 & 11 & 8 & 0 & 8 \\
\hline Ability & 1 & 1 & 2 & 0 & 1 & 1 \\
\hline STEM Subjects & 1 & 0 & 1 & 0 & 0 & 0 \\
\hline Fun/Enjoyable & 0 & 0 & 0 & 0 & 0 & 0 \\
\hline $\begin{array}{l}\text { Engaging/Hands-on } \\
\text { Activities }\end{array}$ & 1 & 0 & 1 & 0 & 0 & 0 \\
\hline Camps & 0 & 0 & 0 & 0 & 0 & 0 \\
\hline
\end{tabular}

Under the category of "Interested in STEM", "Career/Future Plans" was found to be the most abundant factor. It was mentioned by male and female students a total of 133 times. A female student wrote, "I have always found it fascinating how STEM has improved both others and my lives. I have always thought how I could possibly change the world in different ways." Her response indicated that her desire and plan to help others in the future was a reason she was interested in STEM. A male student wrote about his career/future plans being a major reason for his interest in STEM, "Yes I am interested in a STEM career. The reason why I am interested in a STEM career is because I like engineering and I know it is a great pathway for careers."

The subcategory "STEM Subjects" under the main category "Interested in STEM" had the second highest frequency of 55. A male student said, "Yes, engineering has really piqued my interest and I love working with technology." He explained how the subjects engineering and technology inspired his interest in STEM. A female student wrote about her interest in STEM subjects, saying, "I have taken a semester class of STEM and over all I am really intrigued with the whole STEM field."

The fact that students found STEM to be fun/enjoyable was often listed as a reason many students were interested in STEM. This subcategory, "Fun/Enjoyable", had a total frequency of 45. One student wrote, "I am interested in STEM careers because I really enjoy science and math and I would like to discover more on STEM careers. I find these types of subjects fun and interesting to learn." The student's desire to learn more about STEM and also her enjoyment of STEM was the reason for her interest in STEM.

"Ability" and "Camps" were the two subcategories with the lowest frequencies, 8 and 11 respectively. While "Camps" was only mentioned twice as a reason for interest in STEM preceding the camp, it was cited a total of 9 times in the post-camp surveys. A female student wrote, "I'm more inclined to find a STEM career now because of this camp. It gave me opportunities to explore new interests and find careers that I would love doing for the rest of my 
life." She expressed how the camp has greatly impacted her interest in STEM and this factor influenced her to pursue a STEM career path. A male student wrote about how camp impacted him by saying, "I am interested in a STEM career because of camps like the one that I am at right now."

Under the category "Undecided", "Career/future plans" was the most abundant subcategory followed by "STEM subjects". "Career/Future Plans" had total frequency of 19. A female student explained her indecision about STEM when she wrote, "I have thought of a STEM career and how beneficial it may be. I have considered being some kind of engineer. But I lean more toward a career in law." "STEM subjects" was the second most frequent subcategory under "Undecided" with a total frequency of 5. Regarding if he wanted to pursue a STEM career, a male student wrote, "I'm not quite sure, I am not super interested in the Math portion, but the rest I'm pretty good with."

"Career/Future Plans" was also found to be the most frequent subcategory in the main category "Not Interested in STEM", appearing a total of 19 times. A male student expressed his lack of interest in STEM when he wrote, "I am not that interested in a STEM career because, I don't want to go into one of the STEM fields." A female student, writing about her lack of interest in a STEM due to other future ambitions, said, "No, because I want to be an artist which doesn't require science."

The second most frequent subcategory under "Not interested in STEM" was "Ability". This subcategory was only coded a total of 3 times. Stating his disinterest in STEM because of his ability, a student wrote, "Nah because I'm a slow learner." A female student wrote, "No, I love science, but math isn't my best subject sadly it makes me annoyed knowing there is always one right answer a specific ways to solve the problem." The female student pointed to her struggles with math as the reason she wasn't interested in STEM.

\section{Quantitative Data}

This section examined the responses of students when asked to rate their interests in careers in the different STEM fields. The students answered on a scale of 1-5 the questions "I am interested in careers that involve Science", "I am Interested in careers that involve Technology", "I am Interested in careers that involve Engineering", and "I am Interested in careers that involve Mathematics." The averages of the responses to those four questions as the average interest in STEM careers. The survey used was the STEM Career Interest Survey [9].

The results from four different groups of students were analyzed using T-Tests. The categories were: the entire group of students, male students, female students, and students that started the camp with a low interest. A bold font P-value of .05 or less was considered significant.

In Table 8, the results of the T-test from all the students' responses are shown. "I am interested in Math" was seen to have a significant difference following the camp with a value of .009. "STEM average interest" also had a significant difference of .001. The P values for the students' interest in science, technology, and engineering indicated there is no significant difference before and after the camp. 
Table 8: Quantitative Data for the full group of students $N=121$

\begin{tabular}{lcc|cc}
\hline \multicolumn{1}{c}{ Question } & \multicolumn{2}{c|}{ Mean } & Standard & P-Value \\
& Peviation & & \\
\hline Science Career Interest & 3.88 & 4.02 & .0829 & .081 \\
Technology Career Interest & 4.11 & 4.20 & .71 & .16 \\
Engineering Career Interest & 4.01 & 4.13 & .704 & .066 \\
Math Career Interest & 3.65 & 3.83 & .547 & $\mathbf{. 0 0 9}$ \\
STEM Career Interest & 3.913 & 4.043 & .4336 & $\mathbf{. 0 0 1}$ \\
\hline
\end{tabular}

Shown in Figure 2, a bar chart shows the changes in interest before and after the camp in each category. The mean value from the Likert scale is found on the $\mathrm{Y}$-axis, and the $\mathrm{X}$-axis displays the values of each category from the pre and post surveys. The graph shows a trend of an overall increase in interest following the camp.

\section{Full Group Interest in STEM Careers Before and After The Camp}

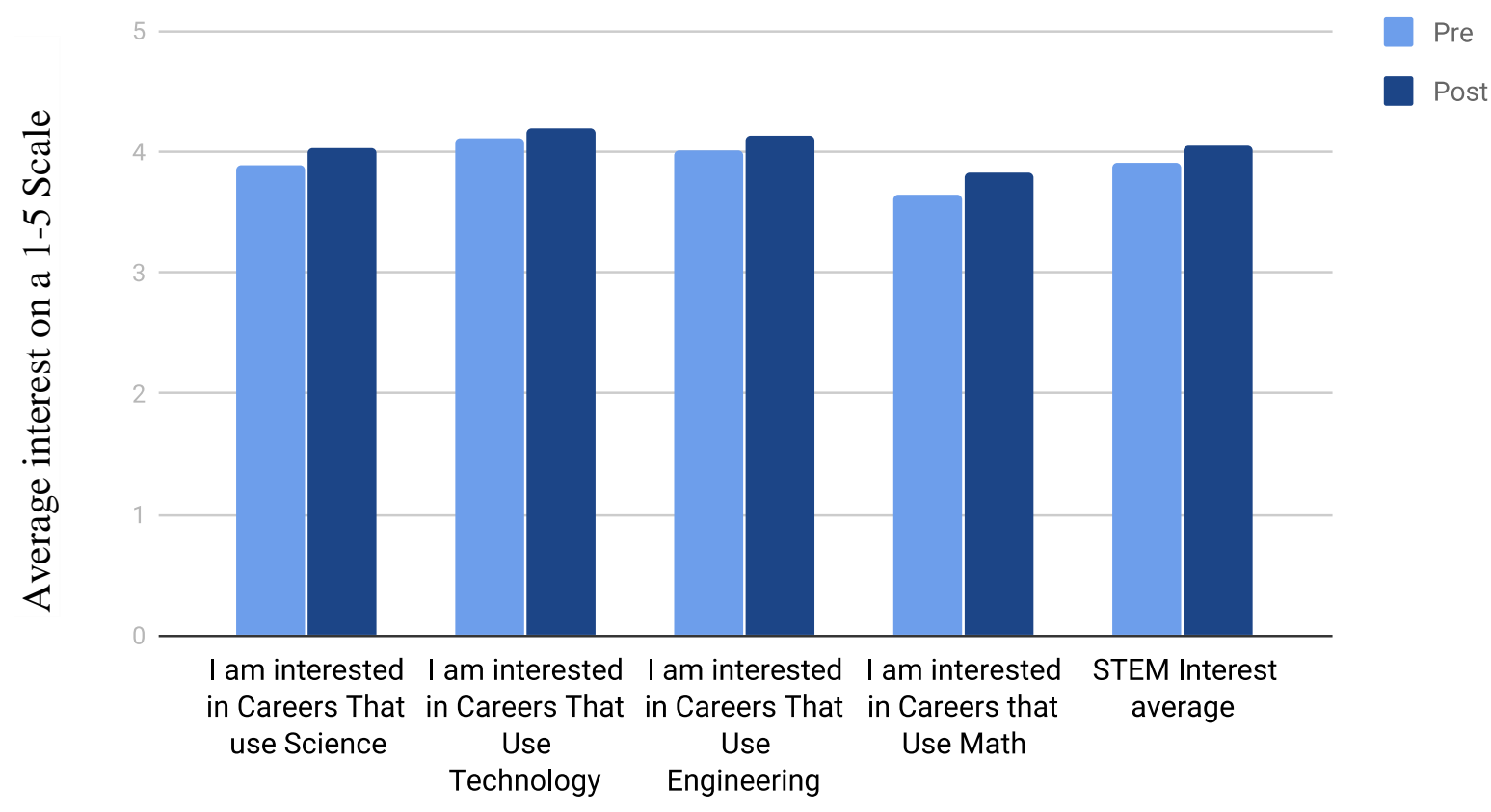

Figure 2: STEM Career Interest for the Entire Group of Students 
Table 9: Quantitative Data for Female Students $N=55$ Male Students $N=66$

\begin{tabular}{|c|c|c|c|c|c|c|c|c|}
\hline \multirow[t]{3}{*}{ Question } & \multicolumn{4}{|c|}{ Mean } & \multirow{2}{*}{\multicolumn{2}{|c|}{$\begin{array}{c}\text { Standard } \\
\text { Deviation }\end{array}$}} & \multicolumn{2}{|c|}{ P-Value } \\
\hline & Male & Male & Female & Female & & & & \\
\hline & Pre & Post & Pre & Post & Male & Female & Male & Female \\
\hline Science Career Interest & 4.02 & 4.11 & 3.73 & 3.91 & .765 & .905 & .334 & .142 \\
\hline Technology Career Interest & 4.29 & 4.31 & 3.89 & 4.07 & .760 & .641 & .871 & .040 \\
\hline Engineering Career Interest & 4.12 & 4.17 & 3.87 & 4.07 & .672 & .704 & .581 & .040 \\
\hline Math Career Interest & 3.58 & 3.77 & 3.73 & 3.91 & .900 & .547 & .103 & .017 \\
\hline STEM Career Interest & 4.00 & 4.09 & 3.81 & 3.99 & .445 & .4336 & .130 & .002 \\
\hline
\end{tabular}

As can be seen in Table 9, there was a significant increase in the mean between the pre and post surveys in all of the categories for the Females that attended this camp, but there was little change in the mean of the males that attended. For Females, there is an overall significant increase in "STEM Career Interest" with a P Value of .002. The questions of "I am interested in Technology", "I am interested in Engineering" and "I am interested in Math" have respective P Values of .04, .04, .017, which deem these as significant. Even with the overall increase in the mean value from pre to post for the question "I am interested in careers that use science", it was not considered significant due to its $\mathrm{P}$ Value of .142.

No male students, the trend was overall positive and male students had an increase in interest between the pre and the post, but that increase was not significant

Figure 2 shows the trends seen in the table more clearly and shows the average male and female interest in the various STEM fields before and after the camp. 


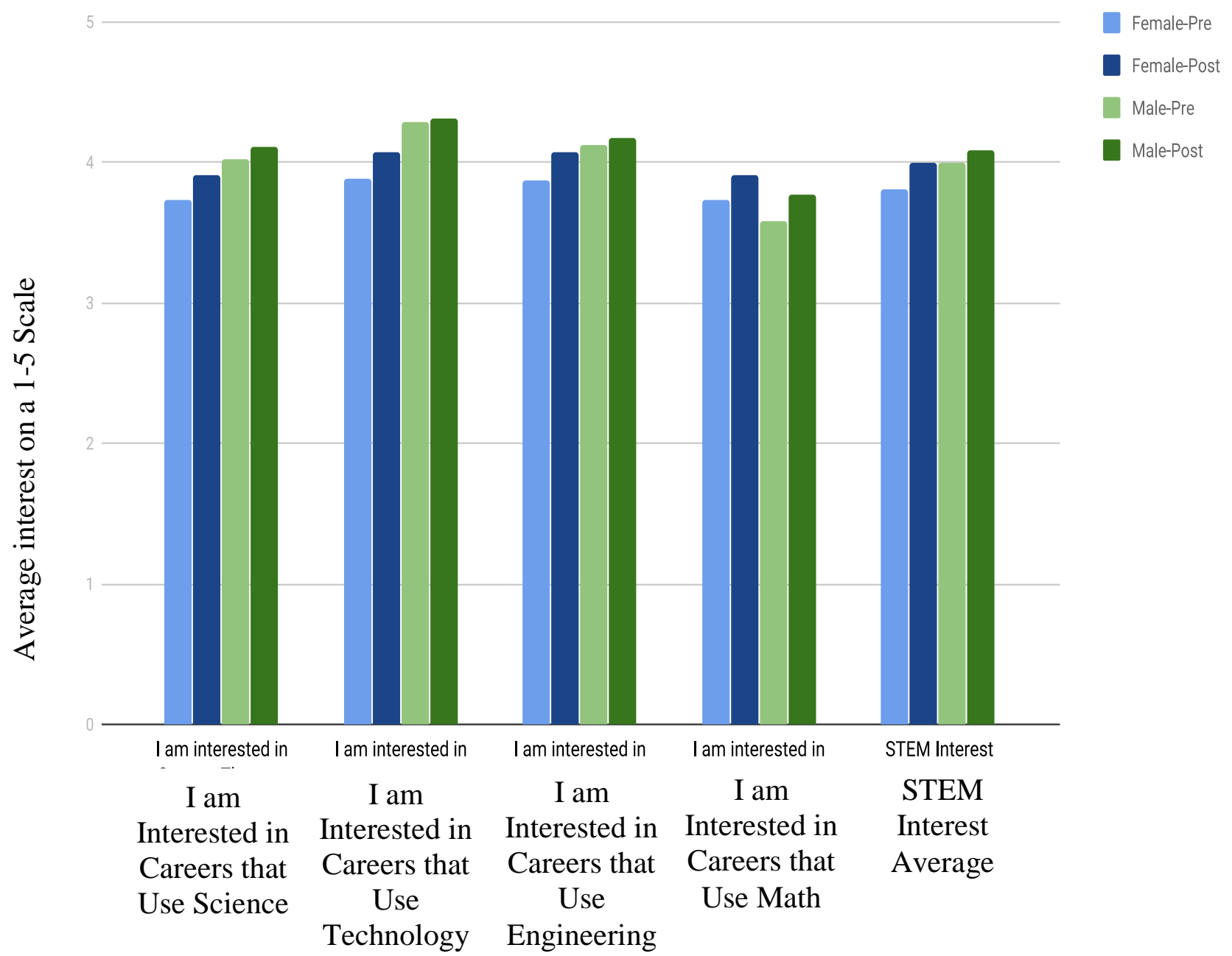

The next section discusses the sub-group that started the camp with low interest in STEM. Low interest was considered to be 3 and lower on a 5-point scale.

In Table 10, the results of the T-test are shown for the different areas of STEM. Forty-six students had low interest in at least one area of STEM before the camp. The table shows that there was a significant increase in every category. The P-value was 0 for all of them, and therefore considered significant. There was a much higher gain in interest for students who started the camp with low interest. 
Table 10: Quantitative Data of Students with Low Interest $N=46$

\begin{tabular}{lcc|cc}
\hline \multicolumn{1}{c}{ Question } & \multicolumn{2}{c|}{ Mean } & Standard & P Value \\
& Peviation & & \\
\hline Science Career Interest & 2.96 & 3.68 & .792 & $\mathbf{0 . 0 0}$ \\
Technology Career Interest & 2.57 & 3.83 & .639 & $\mathbf{0 . 0 0}$ \\
Engineering Career Interest & 2.86 & 3.77 & .684 & $\mathbf{0 . 0 0}$ \\
Math Career Interest & 2.57 & 3.32 & .645 & $\mathbf{0 . 0 0}$ \\
STEM Career Interest & 2.85 & 3.60 & .236 & $\mathbf{0 . 0 0}$ \\
\hline
\end{tabular}

To show those trends more clearly, a bar chart is presented below to show the 46 students who started the camp with low interest.

\section{Sub-Group Interest in STEM Careers Before and After the Camp}

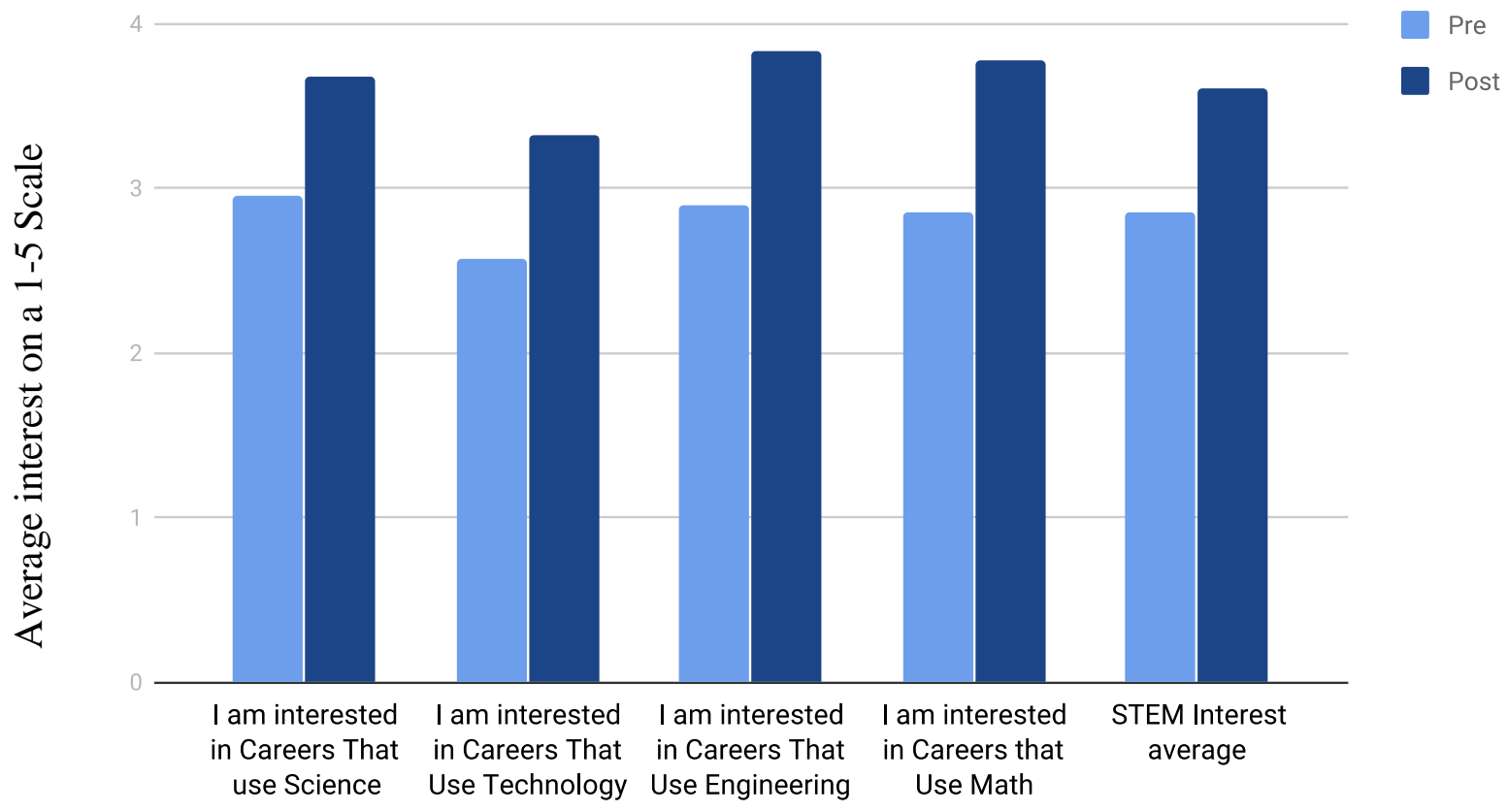

Figure 4: STEM Career Interest for the Sub-Group of Students that Started with Low Interest

\section{Conclusions}

The impact of STEM camps on students' interest in STEM was shown to be significant on many students. Both the qualitative and quantitative data suggested that STEM camps have a positive influence on students' perceptions about STEM. Especially seen in the quantitative data, the 
camp had a significant impact on students who started the camp with low interest. The impact of the camp was also obvious from the quantitative data as the trend is positive for all groups.

While male students in general started the camp with a higher interest level than females, females were seen to have a greater gain in interest after the camp. This was seen in the quantitative data when analyzing P-values for significance and also in the qualitative data when comparing frequencies in the main categories. The camp had a larger impact on the female students and many times was cited by them to be the reason for their interest. Additionally, students starting with low interest had the biggest gain in interest. This suggests that STEM camps should potentially target female students and students who have low interest in STEM.

In studies done by Hernandez et al. [9] and Mahmoud et al. [7], when looking at students in secondary education going into STEM fields, the studies focused on those who came in with an average or low STEM interest, and similar results were found to this research where the students who started with low interest made the biggest gains.

In a study by Lidia Scinski, similar results regarding the impact of STEM summer programs were found. Results show that summer outreach programs positively impacted the middle school students involved and helped them retain some of the learning usually lost during the summer [1]. Thomas et al. discussed how STEM informal summer learning programs provided a valuable opportunity for students to experience STEM in nontraditional ways. The hands-on, interactive learning environment provided by summer STEM programs helped strengthen student interest in STEM and allowed them to form deeper connections with STEM [6][7].

"Career/Future Plans" was found to be the most popular factor influencing students' interest in STEM. Students cited career/future plans to be a very important factor influencing their interest in STEM. This is supported in a study done by April E. Bishop. The study shows that high school students that are interested in STEM are .47 times more likely to pursue a career in those fields [16]. With such a high demand for STEM jobs, it is likely that these students hear about the importance of STEM a lot. This could encourage them to pursue careers and education in those fields.

The impact of informal STEM summer learning programs has the potential to greatly increase student interest in STEM. This makes it a valuable resource that can be utilized to motivate students to enter into the growing fields of STEM. The camp proved to have a significance for two groups of students; females and students who started the camp with low interest. Those groups could potentially greatly contribute to STEM fields. For students with low interest, the data suggests that a summer outreach program could be just what they need to solidify their interest in STEM. Because of the lack of females in many of the STEM fields, there's a high demand for females to pursue STEM careers [17]. Since the data shows the camps had a significance impact on female's interest of STEM, STEM summer camp could be useful in recruiting female students into STEM. Informal STEM summer programs were found to increase STEM interest in all different types of students and demonstrates a lot of potential in helping to close the gap between the number of STEM professionals required by the market and the number of qualified, educated graduates produced by our colleges and universities. 
References

[1] L. Scinski, "Beyond the Classroom: The Impact of Informal STEM Experiences on Student Attitudes and Interest," University of California, San Diego, United States -- California, 2014.

[2] M. Linger, "Plumbing the STEM Pipeline: Exploring Areas of Influence for Promoting STEM Education," Hofstra University, United States -- New York, 2016.

[3] K. Hamrick, “Women, Minorities, and Persons with Disabilities in Science and Engineering," 08-Mar-2019. [Online]. Available: https://ncses.nsf.gov/pubs/nsf19304/digest/field-of-degree-women\#computer-sciences. [Accessed: 1/27/20].

[4] M. Linger, "Plumbing the STEM Pipeline: Exploring Areas of Influence for Promoting STEM Education,” Hofstra University, United States -- New York, 2016.

[5] M. Yilmaz, J. Ren, S. Custer, and J. Coleman, "Hands-On Summer Camp to Attract K-12 Students to Engineering Fields," IEEE Transactions on Education, vol. 53, no. 1, pp. 144151,2010 .

[6] Barger, M., \& Boyette, M. (2015). ROBOTICS CAMPS PROVIDE A STEM-ULATING EXPERIENCE. Techniques, 90(7), 42-46.

[7] M. Mahmoud, K. Becker, M. Longhurst, R. Dupont, N. Menser, and J. Doward, “ Factors Influencing the Interest Level of Secondary Students going into STEM fields and their parents' perceived interest in STEM (Evaluation)," 2017.

[8] T. Roberts et al., "Students' perceptions of STEM learning after participating in a summer informal learning experience," vol. 5, no. 1, pp. 1-14, 2018, doi: http://dx.doi.org.ezproxy.wartburg.edu/10.1186/s40594-018-0133-4.

[9] M. W. Kier, M. R. Blanchard, J. W. Osborne, and J. L. Albert, "The Development of the STEM Career Interest Survey (STEM-CIS)," Research in Science Education, vol. 44, no. 3, pp. 461-481, 2013.

[10] P. R. Hernandez, R. Bodin, J. W. Elliott, B. Ibrahim, K. E. Rambo-Hernandez, T. W. Chen, and M. A. D. Miranda, "Connecting the STEM dots: measuring the effect of an integrated engineering design intervention," International Journal of Technology and Design Education, vol. 24, no. 1, pp. 107-120, May 2013.

[11] P. R. Aschbacher, M. Ing, and S. M. Tsai, "Is Science Me? Exploring Middle School Students' STE-M Career Aspirations," Journal of Science Education and Technology, vol. 23, no. 6, pp. 735-743, Jun. 2014.

[12] J. Saldana, The Coding Manual for Qualitative Researchers. Sage Publications, 2016

[13] J. W. Creswell, Qualitative Inquiry and Research Design: Choosing Among Five Approaches. SAGE Publications. Third Edition, 2012 
[14] J. W. Cohen, Statistical power analysis for the behavioral sciences. New York: Academic Press, 1977.].

[15] J. W. Creswell, Research design: Qualitative, quantitative, and mixed methods approaches. Thousand Oaks, CA: Sage. Fourth Edition, 2013

[16] A. E. Bishop, "Career aspirations of high school males and females in a science, technology, engineering, and mathematics program," University of Maryland, College Park, United States -- Maryland, 2015.

[17] S. Fayer, A. Lacey, and A. Watson, “ STEM Occupations: Past, Present, And Future,” 2017. 